\title{
Relationship between Work-Related Strain Level in Nurses and Their Medical Error Tendency*
}

\author{
Birgül CERIT 1 , Hümeyra HANÇER TOK $\stackrel{0}{2}$, Gülnur TEMELLI 1
}

\begin{abstract}
Aim: The aim of this study is to determine the relationship between work-related strain level and medical error tendency of the nurses.

Material and Methods: The present study was carried out in relational screening model. The data was obtained from 260 nurses. The study data were collected from four state hospitals in a province located in the Western Black Sea region in Turkey between January and March 2017. Approval from the Ethical Committee and institution and verbal consent from the nurses were obtained prior to conducting the study. A descriptive characteristics form, the WorkRelated Strain Inventory (WRSI) and the Medical Error Trend Scale in Nursing (MTSN) were used to collect data. The evaluation of the data was done by descriptive statistics and correlation analysis.

Results: Nurses' work-related strain was found moderate, and their tendency to make medical error was low. A negative, significant, and very weak relationship was found between work-related strain in nurses and medical error tendency related to communication, prevention of falling, patient monitoring and equipment safety, prevention of infections, and medicine and transfusion practices.

Conclusion: As a result of the study, it is seen that work-related strain in nurses affected the medical error tendency significantly and negatively.
\end{abstract}

Keywords: Medical errors; nursing; strain.

\section{Hemşirelerde İşe Bağlı Gerginlik Düzeyi ile Tıbbi Hata Eğilimi Arasındaki İlişki}

Öz

Amaç: Bu çalışmanın amacı hemşirelerde işe bağlı gerginlik ile tıbbi hata eğilimi arasındaki ilişkiyi belirlemektir.

Gereç ve Yöntemler: İlişkisel tarama modeli kullanılarak tanımlayıcı tipte yapılan bu çalışmanın verileri 260 hemşireden elde edilmiştir. Araştırma verileri Ocak-Mart 2017 tarihleri arasında, Batı Karadeniz Bölgesi'nde yer alan bir ildeki dört devlet hastanesinde toplanmıştır. Araştırmanın uygulanabilmesi için etik kuruldan, araştırmanın gerçekleştirildiği kurumlardan ve araştırmada kullanılan ölçekler için yazarlarından yazılı izin ve hemşirelerden sözel onam alınmıştır. Verilerin toplanmasında kişisel bilgi formu, İşe Bağlı Gerginlik Ölçeği ve Hemşirelikte Tıbbi Hataya Eğilim Ölçeği kullanılmıştır. Verilerin değerlendirilmesi tanımlayıcı istatistikler ve korelasyon analizi ile yapılmıştır.

Bulgular: Hemşirelerin işe bağlı gerginliği orta düzeyde, tıbbi hata yapma eğilimlerinin ise düşük olduğu ortaya çıkmıştır. Hemşirelerin işe bağlı gerginlik düzeyi ile iletişim, düşmelerin önlenmesi, hasta izlemi ve malzeme-cihaz güvenliği, enfeksiyonların önlenmesi ve ilaç ve transfüzyon uygulamalarına ilişkin tıbbi hata eğilimleri arasında negatif, anlamlı ve çok zayıf bir ilişki saptanmıştır.

Sonuç: Araştırma sonucunda hemşirelerde işe bağlı gerginliğin tıbbi hata eğilimini anlamlı ve negatif olarak etkilediği görülmüştür.

Anahtar Kelimeler: Tıbbi hatalar; hemşirelik; gerginlik.

1 Bolu Abant Izzet Baysal University, Faculty of Health Sciences, Fundamental of Nursing Department, 14280/Bolu, Turkey

2 Bolu Abant Izzet Baysal University Izzet Baysal Training and Research Hospital, 14280/Bolu, Turkey

* This study was presented as an oral presentation in IV. International Multidisciplinary Congress of Eurasia in Italy, Rome: $23-25$ August 2017.

Sorumlu Yazar / Corresponding Author: Birgül CERiT, e-mail: birgulcerit@yahoo.com.tr

Geliş Tarihi / Received: 27.06.2020, Kabul Tarihi / Accepted: 02.12.2021 


\section{INTRODUCTION}

Today's heavy working conditions and long working hours have caused significant job stress, and this has begun to become a threat to healthcare staff. Health professionals are exposed to intense stress in health institutions (1). The nurses, undertaking most of the services provided at these institutions, may have workrelated strain/stress due to heavy workload, caring patients with poor prognosis and high mortality rate and providing emotional support to patients and their relatives, when necessary (2).

The work-related strain is caused by inadequacies in an individual's abilities, physical or psychological reasons and leads to strain. When the frequency and duration of this strain are higher than an individual's power of coping, problems may occur (1). These problems may be both psychological ones, such as depression, anxiety disorder and physiological effects, such as pain, strain, sleeping disorder (3). The work-related strain may also lead to institutional problems, such as a decrease in work efficiency and professional satisfaction, going work late or not going, leaving job permanently (4). These negative results may cause inadequacies in an individual's professional abilities, and result in medical error tendency. While medical errors concern all healthcare staff, they are of great importance for nurses because they mostly provide service in patient care and treatment administration and may pose a threat for patient safety in case of any misapplication (5).

Medical errors has been a comprehensive issue discussed in the world in terms of ethical, legal, medical, educational and managerial respects in recent years. These medical errors include a wide range of conditions that may occur due to lack of knowledge, ability and negligence at all stages of treatment and care, from medicine use to hospital infections, and these medical errors are harmful to patients and may result in longer healing durations, morbidity and mortality by going on out of normal course of disease (6). It is reported in the literature that the factors such as work overload, stress, communication problems and fatigue that health care professionals have increase the rate of medical error (7), and stress ranks first among these factors (8). Medical errors threating patient safety seriously are one of the leading causes of death in the United States of America (9). It is urged in a study carried out in Netherland that $10 \%$ of all hospital patients suffer from medical errors while more than half of these errors may be avoided (10). Although the rate of medical errors is not known accurately in Turkey, it is reported that it shows similar values seen in other countries (11). On the other hand, it was found out that medicine-related errors are mostly caused by nurses in a study in which medical errors were assessed over Turkish National Security Reporting System (12). The report issued by European Commission (13) argues that the rate of Turkish participant considering medical errors as a significant problem has reached to $90 \%$ and $65 \%$ of these participants are concerned about suffering a severe medical error in Turkey.

The workload, long and irregular working hours that nurses have due to existing health system make working conditions difficult and may cause nurses to get tired physically and mentally (14). Working in an intensive tempo all the time may increase the work-related strain by causing nurses to suffer burnout after a while. Accordingly, working under such difficult conditions in a strained manner may lead to error tendency by making it difficult to concentrate on patient or administration during nursing interventions. This poses a risk for patient safety and causes nurses to suffer in legal respects (5). In this context, the results of this study will provide guidance for improvement to the institutions where nurses work and for the development of institutional policies supporting worker motivation and patient safety. Thus, the current study aimed to determine the relationship between work-related strain and medical error tendency in nurses.

Answers to the following question were sought:

- What are the nurses' opinions about experiencing work-related strain?

- What is the level of medical error tendency of nurses?

- Is there any relationship between work-related strain and medical error tendency in nurses?

\section{MATERIAL AND METHODS}

\section{Study Design}

The present study was carried out in relational screening model.

\section{Study Setting and Sample}

The study population consists of 800 nurses who work at four public hospitals (hospitals are coded as A, B, C and D) in a province located in the Western Black Sea region of Turkey. The literature suggests that a sample size of 260 participants is necessary to represent a population of 800 (15). Therefore, 260 nurses were enrolled in this study. Stratified sampling method was utilized in sample selection. Accordingly, the number of nurses in each hospital was determined and the representation rate of number of nurses in each hospital was calculated within sample volume. As a result of calculations, the nurses constituting the population were selected from following hospitals: 56\% ( $n=146)$ Hospital A, 26\% ( $=68)$ Hospital B, 9\% (n=23) Hospital C and 9\% (n=23) Hospital D.

\section{Data Collection}

The research data was collected in January-March 2017 by using " Descriptive Characteristics Form", "WorkRelated Strain Inventory (WRSI)" and "Medical Error Trend Scale in Nursing (MTSN)". Nurses were invited to study by giving information about the research by the researchers during the data collection phase. The volunteer nurses were given surveys to complete and the completed forms were collected from the participants by the researchers. Survey completion took approximately 20-25 minutes.

\section{Measurements \\ Descriptive Characteristics Form}

The form includes five questions about the nurses' ages, gender, education background, experience as a nurse and current place of employment.

\section{Work-Related Strain Inventory (WRSI)}

The validity and reliability of Turkish version of the "Work-Related Strain Inventory" developed by Revicki and et al. in 1991 were administrated by Aslan et al. in 
1998 (16). The work-related strain inventory is a selfreport type scale of four-point Likert consisting of 18 items developed in order to determine the work-related strain and stress in healthcare professionals. Scale scoring is utilized as follows: 4=I fully agree, $3=\mathrm{I}$ mostly agree, $2=\mathrm{I}$ partially agree and $1=\mathrm{I}$ disagree. Items $2,3,8,9,11$ and 15 are scored reversely. It was reported by Aslan et al. (16) in their validity and reliability study on nurses that excluding the $15^{\text {th }}$ item would increase the reliability since that item decreased item-test correlation. The Cronbach alpha reliability coefficient of the scale was found to be 0.78 after excluding the $15^{\text {th }}$ item (16). This study was also administrated over 17 items, and the Cronbach alpha reliability coefficient was determined to be 0.85 . While the lowest score that can be obtained from the scale was 17 , the highest score was 68 , and as the score obtained increased, the level of work-related strain increased.

\section{Medical Error Trend Scale in Nursing (MTSN)}

This scale, developed in 2010 by Özata and Altunkan in order to measure the tendency of nurses to make medical error, consists of 49 items and five sub-dimensions that include the activities which nurses perform routinely as part of patient care (17). Scale sub-dimensions are communication, prevention of falling, patient monitoring and equipment safety, prevention of infections, and medicine and transfusion practices. Medical Error Trend Scale in Nursing is a 5-point, Likert-type scale, where it is evaluated as $1=$ never, $2=$ rarely, $3=$ sometimes, $4=$ usually, and 5= always. The average score is used in the evaluation of the scale. The higher total scores indicate the lower tendency for medical error. With regard to reliability of the instrument, Özata and Altunkan (17) reported a Cronbach's alpha value of 0.95 . In the study, it was calculated to be 0.85 .

\section{Statistical Analysis}

While number and percentage were utilized in assessing the data related to descriptive characteristics of nurses, mean and standard deviation values were administrated in determining the levels of work-related strain and medical error tendency. The normal distribution of data was tested by skewness and kurtosis values to specify statistical analyses to be utilized in this research. Since skewness and kurtosis values were between +2.5 and -2.5 , it was determined that data had a normal distribution (18) (skewness and kurtosis values for WRSI were 0.427, 0.412, respectively and for MTSN were -1.076, 1.076, respectively). Accordingly, while Pearson correlation analysis was administrated in determining the relationship between the work-related strain and medical error tendency in nurses. The literature urges following definitions related to correlation coefficient power: 0.00 0.25 very poor, $0.26-0.49$ poor, $0.50-0.69$ medium, 0.70 0.89 high, $0.90-1.00$ (18).

\section{Ethical Considerations}

For the approval of the study, written permission was obtained from each hospital. Nurses were informed about the aims and methods of the study. They were told that their participation must be voluntary and were given the right to withdraw from the study at any time. Written informed consent of the nurses was obtained in the study and the principles of the Declaration of Helsinki were followed. Written permission was obtained from the writers for the use of instruments and from the ethical committee (Reference number: 2016/03).

\section{RESULTS}

Table 1 shows the data related to the descriptive characteristics of nurses. Accordingly, $46.5 \%$ of the nurses, were in the age range of 30-41, most of them were female $(70.4 \%)$ and more than half of them $(56.5 \%)$ had a bachelor's degree. It was also achieved that $64.2 \%$ of the nurses were working at medical ward and $43.8 \%$ of them had 10 years or more work experience.

Table 1. Descriptive characteristics of nurses $(n=260)$

\begin{tabular}{|c|c|c|}
\hline Characteristics & $\mathbf{n}$ & $\%$ \\
\hline $\begin{array}{l}\text { Age } \\
18-29 \\
30-41 \\
42+ \\
\end{array}$ & $\begin{array}{l}84 \\
121 \\
55 \\
\end{array}$ & $\begin{array}{l}32.3 \\
46.5 \\
21.2 \\
\end{array}$ \\
\hline $\begin{array}{l}\text { Gender } \\
\text { Female } \\
\text { Male }\end{array}$ & $\begin{array}{l}183 \\
77\end{array}$ & $\begin{array}{l}70.4 \\
29.6\end{array}$ \\
\hline $\begin{array}{l}\text { Educational background } \\
\text { Senior high school } \\
\text { Associate degree } \\
\text { Bachelor } \\
\text { Postgraduate } \\
\end{array}$ & $\begin{array}{l}38 \\
71 \\
147 \\
4 \\
\end{array}$ & $\begin{array}{l}14.6 \\
27.3 \\
56.5 \\
1.6 \\
\end{array}$ \\
\hline $\begin{array}{llll}\begin{array}{l}\text { Experience as a } \\
\text { (years) }\end{array} & & & \\
0-4 & & & \\
5-9 & & & \\
10+ & & & \\
\end{array}$ & $\begin{array}{l}50 \\
96 \\
114 \\
\end{array}$ & $\begin{array}{l}19.3 \\
36.9 \\
43.8 \\
\end{array}$ \\
\hline $\begin{array}{l}\text { Current place of } \\
\text { employment } \\
\text { Medical ward } \\
\text { Surgical ward } \\
\text { Intensive care unit }\end{array}$ & $\begin{array}{l}167 \\
54 \\
39 \\
\end{array}$ & $\begin{array}{l}64.2 \\
20.8 \\
15.0 \\
\end{array}$ \\
\hline Total & 260 & 100.0 \\
\hline
\end{tabular}

n: Frequency, \%: Percent

Table 2. Mean scores of nurses obtained from total Medical Error Trend Scale in Nursing and their subdimensions and Work-Related Strain Inventory

\begin{tabular}{|c|c|c|c|}
\hline Instruments & $\mathbf{X} \pm \mathbf{S D}$ & $\begin{array}{l}\text { Min-Max } \\
\text { Values of } \\
\text { the Scale }\end{array}$ & $\begin{array}{l}\text { Min-Max } \\
\text { Values of } \\
\text { the Study }\end{array}$ \\
\hline $\begin{array}{l}\text { Sub-dimensions } \\
\text { of MTSN }\end{array}$ & & & \\
\hline Communication & $4.55 \pm 0.43$ & $1-5$ & $3.20-5.00$ \\
\hline $\begin{array}{l}\text { Prevention of } \\
\text { Falling }\end{array}$ & $4.49 \pm 0.46$ & $1-5$ & $3.20-5.00$ \\
\hline $\begin{array}{l}\text { Patient } \\
\text { Monitoring and } \\
\text { Equipment Safety }\end{array}$ & $4.45 \pm 0.45$ & $1-5$ & $3.11-5.00$ \\
\hline $\begin{array}{l}\text { Prevention of } \\
\text { Infections }\end{array}$ & $4.53 \pm 0.69$ & $1-5$ & $3.08-5.00$ \\
\hline $\begin{array}{l}\text { Medicine and } \\
\text { Transfusion } \\
\text { Practices }\end{array}$ & $4.54 \pm 0.36$ & $1-5$ & $2.94-5.00$ \\
\hline Total MTSN & $4.53 \pm 0.32$ & $1-5$ & $3.16-5.00$ \\
\hline Total WRSI & $39.56 \pm 8.56$ & $17-68$ & $21-53$ \\
\hline
\end{tabular}

X: Mean, SD: Standard Deviation, Min: Minimum, Max: Maximum, MTSN: Medical Error Trend Scale in Nursing, WRSI: Work-Related Strain Inventory 
Table 2 shows the data related to mean scores that nurses obtained in WRSI, MTSN and their sub-dimensions. It was found out that while WRSI mean score of nurses was $39.56 \pm 8.56(\min =21, \max =53)$, their mean score for MTSN was $4.53 \pm 0.32(\min =3.16, \max =5.00)$. It was concluded that whereas the work-related strain of nurses was at medium level, their medical error tendency was low. The mean MTSN subscale scores were $4.55 \pm 0.43$ in communication, $4.49 \pm 0.46$ in prevention of falling, $4.45 \pm$ 0.45 in patient monitoring and equipment safety, $4.53 \pm 0.69$ in prevention of infections, and $4.54 \pm 0.36$ in medicine and transfusion practices.

Table 3. The relationship between nurses' work-related strain and their medical error tendency

\begin{tabular}{|l|l|l|}
\hline $\begin{array}{l}\text { Sub-dimensions of } \\
\text { MTSN }\end{array}$ & \multicolumn{2}{|l|}{ WRSI } \\
\cline { 2 - 3 } & $\mathbf{r}$ & $\mathbf{p}$ \\
\hline $\begin{array}{l}\text { Communication } \\
\text { Prevention of Falling } \\
\text { Patient Monitoring and }\end{array}$ & -0.192 & $0.002^{* *}$ \\
Equipment Safety and & -0.154 & $0.006^{* *}$ \\
Prevention of Infections & -0.229 & $0.013^{*}$ \\
Medicine & -0.223 & $0.000^{* * *}$ \\
Transfusion Practices & & \\
\hline
\end{tabular}

$* \mathrm{p}<0.05, * * \mathrm{p}<0.01, * * * \mathrm{p}<0.001, \mathrm{p}:$ Significance Level, MTSN: Medical Error Trend Scale in Nursing, WRSI: Work-Related Strain Inventory

Table 3 shows the results of the correlation analysis conducted to determine whether there was a relationship between nurses' work-related stress and their tendency to make medical errors. Accordingly, a negative, significant and very weak relationship was found out between nurses' work-related strain level and communication ( $\mathrm{r}=$ $0.192, \mathrm{p}<0.01)$, prevention of falling $(\mathrm{r}=-0.170, \mathrm{p}<0.01)$, patient monitoring and equipment safety $(\mathrm{r}=-0.154$, $\mathrm{p}<0.05)$, prevention of infections $(\mathrm{r}=-0.229, \mathrm{p}<0.001)$, and medicine and transfusion practices $(\mathrm{r}=-0.223$, $\mathrm{p}<0.001$ ), which are the sub-dimensions of MTSN.

\section{DISCUSSION}

The large number of stressors in the healthcare sector, tiring and intense working conditions, and the fact that the service provided is human centered can increase nurses' work-related strain. Working under this strain can increase the tendency for nurses to tend to make medical errors that may threaten patient safety while performing their nursing practices. The work-related strain in nurses was found to be at medium level in this research. When searching the related literature, it was concluded that while the results of some studies $(1,19,20)$ had similarities to our study, the studies arguing different results were also found $(14,21,22)$. The work-related strain in nurses relates to all events in which nurses perceive work-related situations as a threat or danger, to which they comply with when institutions provide proper environments and feel threatened if appropriate environments are not ensured by institutions, and they may be effective on care behaviours (19). Nurses may suffer the work-related strain due to working in night shift, caring for the patients with poor prognosis, high number of patients per nurse, working at clinics with heavy workload and lack of administrative support (14). In addition, starting working as a nurse in recent times causes strain in nurses (21). The work-related strain leads firstly to individual problems, such as low working performance, decreased quality of patient care, unwillingness to go work and leaving work and these individual problems are followed by institutional ones (22). Since the nurses with low motivation and high work-related strain may suffer attention deficit and stress, this process may result in decreased quality of patient care, irregular patient follow-up and administration errors. What is more, it is urged in one study (1) that as the work-related strain increased in nurses, their selfconfidence and optimism decreased while their submissive behaviors increased. In this study, although the work-related strain of nurses was found to be medium but not high, this still suggests that any situation threating patient safety may occur in patient care services, quality of care may decrease and individual and institutional problems may be encountered.

It was found out in this study that the nurses had a low medical error tendency. When searching the related literature, it was achieved that prior studies on medical error tendency reported similar results $(5,23,24-26)$ to this study while the research by Akgun and Kardas (4) concluded a higher medical error tendency in nurses than the present study. Medical errors lead to longer duration of hospital stay, higher mortality and morbidity and negative effects on a patient, his/her family and healthcare professionals (24). Low medical error tendency is of importance in providing a more quality service to patients, prevention of infections, strict fulfillment of patient follow-up, providing a safe environment for patients and effective communication. In addition, low medical error tendency leads to costeffective working in medical institutions, avoiding unnecessary expenses and workforce loss $(6,25)$. Identifying individual and system-related factors causing any medical error are important in achieving low medical error tendency. In this regard, related literature argues that medical error tendency could be reduced in nurses by following factors: increase in educational level, working time less than eight hours, a sense of responsibility in the nurse undertaking treatment of a patient, working with sufficient equipment, adequate decision support systems etc. $(24,27)$. Low medical error tendency is considered both an indicator of a quality and prestigious institution and a reason for preference of patients (25). For this reason, low medical error tendency of nurses in this study may be considered as positive. It was found in this research that there was a negative, significant and very weak correlation between nurses' work-related strain and their medical error tendency related to communication. When looking at studies in the literature, it is argued that medical error rate of healthcare professionals increases depending on work stress s/he has (28-30). Lack of communication, especially between doctor and nurse or communication problems between other health care team 
and a patient may lead to medical errors originating from ineffective communication (31). The work stress that nurses have along with increasing workload brings along medical error risk (23). However, when considering that the work-related strain of nurses was in medium level in this study, it can be said that this stress level caused a positive effect on nurses and thus, the medical error tendencies due to communication showed decrease. Stress is not always bad; the significant thing is to what extent stress is experienced. Stress from low to moderate has a constructive and energizing effect (32). Extreme stress affects an individual's physical and mental system negatively and make it out of use. Productivity is at its optimum level when employees have a medium level of stress. What is more, a medium level of stress has an effect of encouraging an individual to work in his/her job carefully, stimulating creativity, increasing his/her effort and giving energy (32). Therefore, it can be argued that the medium level work-related strain in nurses increased their success in establishing a balanced relationship with healthcare professionals and decreased their medical error tendency based on communication. This is of importance in providing a quality and safe patient care, strengthening the team spirit and achieving institutional goals.

It was found in this research that there was a negative, significant and very weak correlation between nurses' work-related strain and their medical error tendency related to prevention of falling. Falls are one of the main problems threatening patient safety. The literature states that falls are among the most common accidents in hospitals $(33,34)$. Complications that develop after a fall can threaten the life of the patient, negatively affect quality of life, and increase the duration of hospital stays and treatment costs (33-35). It is important for nurses to determine the risks related to the patients they are caring for and take appropriate measures in order to prevent these problems. Nurses' awareness and attention is an effective factor in preventing falls. In this study, mediumlevel work-related strain, as a stimulus, had a positive impact on nurses' attention to prevent patients from falling and their ability to use effective methods, and it reduced the tendency to make medical errors regarding the prevention of falls.

This study achieved that there was a negative, significant and very weak correlation between nurses' work-related strain and their medical error tendency related to patient monitoring and equipment safety. Using improper materials result in misguidance in treatment and nursing care, failure in patient follow-up and undesirable results in any patient. Nurses may face legal problems in such a case (26). Using improper material or misuse of a device and using any material without checking in any medical institution may lead to patient's receiving an ineffective treatment, longer healing duration and cost increase for both patient and institution (5). Therefore, maintenance of devices and checking (expiry date, sterilization process, etc.) consumables to be used are of importance in preventing errors related to nursing care and safe patient follow-up $(36,37)$. In addition, determining appropriate intervals for patient follow-up and nurses' visits to patients, implementing necessary controls, and recording patient data are important for improving patient prognosis. Therefore, the care and attention of healthcare professionals are important for correct and appropriate patient follow-up, determining the suitability of the materials used, and calibrating the devices. In this context, a medium level of work-related strain in nurses can play an important role in reducing their tendency to make medical errors resulting from patient monitoring and equipment safety by encouraging them to do their jobs more attentively and willingly and increasing their attention. This result can be regarded as positive in terms of its reflections on safe and qualified patient care.

This study found that there was a negative, significant and very weak correlation between nurses' work-related strain and their medical error tendency related to prevention of infections. Infections, which are significant problems across the world and in Turkey, result in longer duration of hospital stay, patients' living physiological, psychological and social problems, increasing morbidity and mortality rates in hospitals and increasing treatment costs (37). It is known that nurses have the fear of making errors due to long working hours in administration of care and treatment for a patient, insufficient staff/time/ medical equipment and infection transmission risk and this fear causes them to live strain (38). As a result of this strain, it is considered that nurses behave more carefully in care and treatment administration processes to protect themselves and their patients from infection, to reduce cost, to prevent potential additional interventions to be administrated to a patient. What is more, when low infection rate is considered as a sign of patient safety and quality, low medical error tendency related to prevention of infection is of importance in achieving individual and institutional goals. It is emphasized in the literature that the relationship between stress and work productivity depends on the amount of stress, and work performance will decrease in the event of no stress in the work environment. Normal level stress is a stimulus encouraging workers to struggle (32). Accordingly, it is considered that the medium level work-related strain of nurses affected their performances positively and decreased their medical error tendency related to prevention of infections. It can be said that this is important in providing a safe patient care, shortening the healing process of patients, providing cost-effective services and achieving institutional goals.

It was found in this study that there was a negative, significant and very weak correlation between nurses' work-related strain and their medical error tendency related to medicine and transfusion practices. The error related to medicine and transfusion practices is one of the most seen errors in nursing (39). Not following medicine preparation/practical guides, not applying basic standards and lack of knowledge may cause administration errors (40). These errors both extend the healing period of patients and lead to many health problems. In addition, nurses may face legal problems as a result of improper medicine and transfusion practices (39) and suffer from material and non-material sanctions. In this study, the medium level work-related strain of nurses is considered to be important in reducing medical error tendency related to medicine and transfusion practices, and decreasing or preventing above-mentioned negative situations. Since the work-related strain of nurses, which may be characterized as constructive, has a motivating 
effect on them by leading them to commit their works and to do their work more willingly, their work performances will increase (32) because a medium level strain has a positive effect on individuals' care abilities (22). Therefore, a normal level stress, characterized as a healthy stimulant, has a positive effect on nurses' excitement and attention levels they need when performing their administrations, may support their decision abilities, and may reduce their error rate by increasing their motivation. In this regard, when considering that nurses had a medium level of workrelated strain in this study, it can be urged that this is effective in reducing the medical error tendency related to medicine and transfusion practices. This is of importance in the fulfillment of safe administration, quality patient care, cost-effective treatment and preventing nurses to face any legal process.

\section{CONCLUSION}

In this study, the work-related strain of nurses was found to be at medium-level while their medical error tendency was determined to be low. It was concluded that a negative, significant, and very weak relationship was found between work-related strain in nurses and medical error tendency related to communication, prevention of falling, patient monitoring and equipment safety, prevention of infections, and medicine and transfusion practices.

Considering that extreme stress may trigger the medical errors that may occur during nursing practices, it may be suggested to provide institutional motivations keeping the work-related strain of nurses in a constructive level, to support effective guidance and counselling services in order to cope with stress, to improve working conditions, to develop institutional policies guiding in decisions to be taken and maintaining within-team dynamics.

Authors's Contributions: Idea/Concept: B.C., H.H.T; Design: B.C., H.H.T; Data Collection and/or Processing: H.H.T., G.T.; Analysis and/or Interpretation: B.C., G.T.; Literature Review: B.C., H.H.T., G.T.; Writing the Article: B.C., H.H.T., G.T.; Critical Review: B.C.

\section{REFERENCES}

1. Aksu İ, Erdim A. How do operating room nurses cope with work-related tension and stress? Turkiye Klinikleri J Nurs Sci. 2018; 10(1): 28-37.

2. Erçevik R. Work-related strain, burnout, and contributing factors among nurses [Master thesis]. İstanbul: Haliç University; 2010.

3. Qiao S, Li X, Zhou Y, Shen Z, Stanton B. Attitudes toward evidence-based practices, occupational stress and work-related social support among health care providers in China: a SEM analysis. PLOS One. 2018; 13(8): 1-16.

4. Akgün Şahin Z, Kardaş Özdemir F. Examination of the tendency of nurses to make medical errors and the affecting factors. Koç Üniversitesi HEAD. 2015; 12(3): 210-4.

5. Karaca Sivrikaya S, Şimşek Kara A. Determination the tendency of the nurses to make medical mistake. Balıkesir Sağlık Bil Derg. 2019; 8(1): 7-14.
6. Birgili F, Köse, F. Tendencies of nurses to medical errors. Journal of Current Researches on Health Sector. 2018; 8(2): 249-66.

7. Keers RE, Williams SD, Cooke J, Ashcroft DM. Causes of medication administration errors in hospitals: a systematic review of quantitative and qualitative evidence. Drug Saf. 2013; 36(11): 104567.

8. Salam A, Segal DM, Abu-Helalah MA, Gutierrez ML, Joosub I, Ahmed W, et al. The impact of workrelated stress on medication errors in Eastern Saudi Arabia. Int J Qual Health Care. 2019; 31(1): 30-5.

9. Makary MA, Daniel M. Medical error-the third leading cause of death in the US. BMJ. 2016; 353: 15 .

10. Smits M, Zegers M, Groenewegen PP, Timmermans DR, Zwaan L, van der Wal G, et al. Exploring the causes of adverse events in hospitals and potential prevention strategies. Qual Saf Health Care. 2010; 19(5): 1-7.

11. Er F, Altuntaş S. Determination of nurses' viewpoints about medical errors and their causes. Journal of Health and Nursing Management. 2016; 3(3): 132-9.

12. Çakmak C, Konca M, Teleş M. The evaluation of medical errors through Turkey National Safety Reporting System (SRS). Hacettepe Journal of Health Administration. 2018; 21(3): 423-48.

13. Ec.europa.eu [Internet]. Special Eurobarometer: Medical Errors. [Cited: 2020 March 23]. Available from:https://ec.europa.eu/commfrontoffice/publicopin ion/archives/ebs/ebs_241_en.pdf.

14. Akbulut Başçı AB, Özyurda F, Yılmazel G. The level of work related tension and role conflict-role ambiguity status of nurses working in Ankara University Hospitals. JAREN. 2016; 2(2): 51-8.

15. Ural A, Kılıç İ. Bilimsel araştırma süreci ve SPSS ile veri analizi. 4. baskı. Ankara: Detay Yayıncılık; 2013.

16. Aslan SH, Alparslan ZN, Aslan RO, Kesepara C, Ünal M. Validity and reliability of Work-Related Strain Scale in health care workers. Düşünen Adam: Psikiyatri ve Nörolojik Bilimler Dergisi. 1998; 11(2): 4-8.

17. Özata M, Altunkan H. Developing the scale of nurses' medical error tendency and validity and reliability analysis. Kırılmaz E, editor. II. Uluslararası sağlıkta performans ve kalite kongresi, bilimsel araştırma \& en iyi uygulama ödülleri kitabı; Ankara: Sağlık Bakanlığı Yayınları; 2010. s. 3-20.

18. Kocaçalışkan İ, Akalın Bingöl N. Biyoistatistik. 3. baskı. Ankara: Nobel Akademik Yayıncılık; 2017.

19. Özver Y. Workload perception, work-related stress and medical error attitudes of nurses working in surgical clinics [Master thesis]. Ordu: Ordu University; 2016.

20. Kopuz E. Determination of the level of nurses' workrelated strain and examining the attitudes of coping with stress: example of a special hospital [Master thesis]. İstanbul: Haliç University; 2013.

21. Açık Y, Yiğitbaş Ç, Bulut A, Deveci SE, Pirinçci E, Oğuzöncül AF, et al. Work-related tension, using the methods of overcoming the stress and the affecting factors in emergency staff. Turkiye Klinikleri J Med Sci. 2016; 36(1): 22-9. 
22. Avcı GG, Öztürk G, Azaklı N, Çekinmez ST. Determination of work-related stress levels of nurses and style of coping with stress. İKÇÜSBFD. 2018; 3(1): 1-7.

23. Aydın Sayılan A, Mert Boğa S. Determination of relationship between job stress, job demands, job control, social support level and tendency to make medical errors of nurses. HEMAR-G. 2018; 20(1): 122.

24. Küçükoğlu S, Ası Karakaş S, Çelebioğlu A. The tendency of nurses to make medical errors and associated impacting factors. International Refereed Journal of Nursing Researches. 2016; 8: 88-102.

25. Öztürk YE, Özata M. The research of the relation between organizational citizenship behavior and malpractice trend in nurses. Süleyman Demirel University The Journal of Faculty of Economics and Administrative Sciences. 2013; 18(3): 365-81.

26. Seren İntepeler Ş, Soydemir D, Güleç D. Medical error tendencies and the factors affecting these tendencies in nurses. Journal of Ege University Nursing Faculty. 2014; 30(1): 1-18.

27. Cebeci F, Gürsoy E, Tekingündüz S. Determining the level of tendency in malpractice among nurses. Journal of Anatolia Nursing and Health Sciences. 2012; 15(3): 188-96.

28. Bondevik GT, Hofoss D, Husebø BS, Tveter Deilkås EC. Patient safety culture in Norwegian nursing homes. BMC Health Serv Res. 2017; 17(424): 1-10.

29. Botha E, Gwin T, Purpora C. The effectiveness of mindfulness based programs in reducing stress experienced by nurses in adult hospital settings: a systematic review of quantitative evidence protocol. JBI Database of Systematic Reviews \& Implementation Reports. 2015; 13(10): 21-9.

30. Barbe T, Kimble LP, Rubenstein C. Subjective cognitive complaints, psychosocial factors and nursing work function in nurses providing direct patient care. J Adv Nurs. 2018; 74: 914-25.

31. Eren Fidanc1 B, Yıldız D, Konukbay D, Akyol M, Akbayrak, Hatipoğlu S. Assessment of the malpractice tendencies of nurses working in an educational and research hospital. Int J Caring Sci. 2014; 7: 294-305.

32. Eren Gümüştekin G, Öztemiz AB. Productivity and performance interaction with stress of organizations. ÇÜSBED. 2005; 14(1): 271-88.

33. Karaman Özlü Z, Yayla A, Özer N, Gümüş K, Erdağ 1 S, Kaya Z. Risks of falling in surgical patients. Kafkas J Med Sci. 2015; 5(3): 94-9.

34. Özden D, Karagözoğlu Ş, Kurukız S. Determination of fall risk according to Hendrich II and Morse Fall Scale: a pilot study. Journal of Anatolia Nursing and Health Sciences. 2012; 15(2): 80-8.

35. Oyur Çelik G, Zıngal H. The determination of falling risk of patients and precautions taken in neurosurgery clinic. İKÇÜSBFD. 2016; 1(1): 7-11

36. Andsoy II, Kar G, Öztürk Ö. A study on trends to medical error for nurses. Journal of Health Sciences and Professions. 2014; 1(1): 17-27.

37. Avşar G, Atabek Armutçu E, Karaman Özlü Z. Determining the level of tendency in malpractice of nurses: a hospital sample. Journal of Health Sciences and Professions. 2016; 3(2): 115-22.

38. Kılıç Ü, Yön B, Şişman N. The relationship between work-related stress and the risk of anxiety and depression of emergency station personnel. Turk $\mathbf{J}$ Public Health. 2019; 17(2): 143-52.

39. Yiğitbaş Ç, Oğuzhan H, Tercan B, Bulut A, Bulut A. Nurses' perception, attitudes and behaviors concerning malpractice. Anatolian Clinic Journal of Medical Sciences. 2016; 21(3): 207-14.

40. Ayorinde MO, Alabi PI. Perception and contributing factors to medication administration errors among nurses in Nigeria. IJANS. 2019; 11: 1-8. 